Нелли Александровна Красовская

Тульский государственный педагогический университет им. Л. Н. Толстого

nelli.krasovskaya@yandex.ru
УДК 811.161.1'28:39

https://doi.org/10.18485/slavistika.2018.22.2.15

оригинални научни рад

примљено 28.02.2018

прихваћено за штампу 04.10.2018.

\title{
ТЕРМИНОЛОГИЯ СВАДЕБНОГО ОБРЯДА В ЮЖНОРУССКИХ ГОВОРАХ: НЕКОТОРЫЕ ДАННЫЕ
}

В статье рассматриваются устойчивые выражения, которые являются частью свадебной терминологии. Подобные выражения зафиксированы на территории южнорусского наречия (тульские говоры) и отражают структуру южнорусской свадьбы. Данные выражения соответствуют предсвадебному, свадебному и послесвадебному этапу. В основном они символически называют основные действия, которые совершают участники свадебного обряда, поэтому по структуре их можно отнести к глагольным словосочетаниям.

Ключевые слова: русские говоры, тульская группа, русская свадьба, свадебная терминология, устойчивые выражения.

The article deals with some idiomatic expressions that are part of wedding terminology. Similar expressions are recorded on the territory of the South Russian dialect (Tula dialects) and reflect the structure of the South Russian wedding. These expressions correspond to the pre-wedding, wedding and post-wedding stages. They are symbolically called the basic actions of the participants of the wedding ceremony, so they can be attributed to the verb phrase via their structure.

Key words: Russian dialects, Tula group, Russian wedding, wedding terminology, sustainable expressions.

Свадебный обряд является одним из главных обрядов любого народа. В этнической традиции славян свадьба занимает центральное место как часть системы семейных обрядов и ритуалов. О русской свадьбе писали многие исследователи, в частности известны современные работы А.В. Гуры, Н.В. Зорина, М.В. Костромичевой, С.М. Толстой и др., которые указывают на сложность, многоэтапность и чрезвычайную семантическую нагруженность данного обряда. В южнорусской традиции свадьбу понимают как свадьбу-веселье, как переход к новой жизни, поэтому она чаще всего сопровождается общим радостным эмоциональным фоном, смешными персонажами и т.д.

Мы ориентируемся на языковой и частично фольклорный материал, который был в течение последних десяти лет зафиксирован на территории одного из регионов южнорусского наречия, а именно на территории бытования тульских говоров. Можно в принципе говорить о том, что все основные культурные, языковые, ментальные особенности, характеризующие южнорусские говоры, отмечаются и в тульских. Тем не менее, исследователи свадебного обряда неоднократно отмечали, что его структура в тульском регионе далеко не однозначна и не так проста. По мнению фольклористов, на территории распространения тульских говоров пересекаются некоторые черты свадьбы-веселья как типа южнорусской свадьбы и свадьбы-похорон как типа севернорусской свадьбы, то есть, скорее, этот тип свадьбы можно отнести к среднерусскому типу. Так, Ю.В. Гайсина подчеркивает: «Как известно, на восточнославянских терри- 
ториях исследователи выделяют два типа свадьбы: свадьба-«веселье» (южный тип) и свадьба-«похороны» (северный тип). Каждому типу обряда свойственны индивидуальные характеристики...Верхнеокская свадьба сочетает черты обоих типов ритуала...» (Гайсина 2007: 348). Наши наблюдения позволяют делать выводы о том, что в структуре свадебного обряда, бытующего в тульском регионе, отмечаются южнорусские и некоторые севернорусские черты.

Обращаясь в своих исследованиях к языковой стороне рассматриваемого обряда, мы прежде всего останавливаемся на тех единицах, которые репрезентируют как отдельные действия, так и некоторые целостные явления свадебного комплекса. В определенной степени новизна нашей работы видится во введении в научный обиход некоторого количества устойчивых сочетаний, относящихся к свадебной терминологии, и речений, их сопровождающих. Фиксация в полевых условиях подобного материала до сих пор является насущной проблемой как фольклористики, так и диалектологии и важна для изучения культуры и языка любого этноса.

Собранные нами устойчивые выражения отражают структуру свадебного обряда, то есть называют действия, которые характерные для различных этапов свадебного комплекса. Такие выражения еще живы в памяти населения нашего региона (поясним, что здесь отражен материал, который собирался нами в течение последнего десятилетия от 70-95-летних носителей диалекта). Однако нельзя говорить, что сейчас свадебный комплекс сохранен в своем традиционном и архаическом виде, конечно, целый ряд этапов и отдельных действий утрачен, но еще в 50-80-е годы XX века зафиксированные нами выражения использовались очень активно. Традиционный свадебный обряд был многодневным и состоял из нескольких этапов. Обычно выделяют предсвадебный этап, саму свадьбу и послесвадебный этап. В наших записях часто встречаются рассказы о том, что свадьба проходила два-три дня, но, например, в с. Иевлево Богородицкого района Тульской области была записана информация о том, что свадьба могла длиться 5 или 6 дней.

В ходе предсвадебного обряда происходило знакомство семей, дети которых собирались вступать в брак, знакомство самих невесты и жениха, обсуждение того, как будет проходить свадьба.

Зафиксированные выражения довольно подробно освещают предсвадебный этап. Последовательность реальных действий несколько отличается в рассказах информантов, имеется определенная вариативность, но в целом к предсвадебному этапу можно отнести такие выражения, как приходить за рубахой ('часть предсвадебного ритуала - первый приход жениха в дом к невесте для снятия мерки, по которой невеста шила жениху свадебную рубаху'). Сваталися, сваты приходили, потом вечер проводили, за рубахай приходили жених с дружкой. (д. Кураково, Бел.) (сами выражения и речения взяты из картотеки тульских говоров, их сопровождает указание на населенный пункт и район фиксации или иной источник Н.К.); кидать кости ('в процессе предсвадебного этапа под стол бросать кости и соревноваться в том, чья родня их захватит'). Приносили курииу, съедали, а кости кидали под стол. (с. Иевлево, Богор.); лапшу хлебать ('часть свадебного обряда, в ходе которой подруги невесты ходят к жениху и со стола воруют продукты'). $A$ ходили еще девки лапшу хлебать, кто какой кусок унесет. (с. Иевлево, Богор.). В 
этих выражениях репрезентируются разнообразные визиты сторон с различными целями в процессе подготовки к самому свадебному действу.

Довольно устойчивой выглядит такая часть предсвадебного обряда, как знакомство родственников невесты с домом жениха, осмотр хозяйства, двора, самого жилья. Этот процесс называется несколько по-разному, но ключевыми глаголами для обозначения указанных действий являются глаголы смотреть, мерить, считать. Значительно варьируются в устойчивых выражениях лексемы, связанные с указанием на то, что именно необходимо смотреть: это могут быть кольишки (колушки), лавки, полати, колья, дом, поместье. В абсолютном большинстве случаев в основе подобных выражений лежит метонимия: вместо указания на целый дом или усадьбу обозначается только какая-то часть: лавочка, полати, кольшки. На наш взгляд, частотное использование именно данных лексем в подобных выражениях символично, так как они обозначают определенную границу или какую-то часть, которая семантически связана с продолжением рода: скамья, полати. К подобным выражениям мы относим: дом смотреть ('часть свадебного обряда, в ходе которого родственники со стороны невесты производят осмотр дома и хозяйства жениха'). Дом смотреть приходили - это как кольшки смотреть ходят. (д. Ливенское, Лен.); колушки (кольшки) смотреть (мерить) (употребляется в указанном выше значении). У жениха колущки смотреть ходили. Это заведенье такое перед свадьбой было. (п. Арсеньево, Арсен.). Колушки смотрели. Ну приходили смотреть колушки, как живуть. (с. Николо-Жупань, Одоев.). Жених сватается, а в ответ визит в дом жениха: смотрели, обмеряли колышики. Невеста должна была сшить шторы на окна. (с. Стояново, Одоев.). Кольишки ездили смотреть, на блины к невесте ездили. Под самую свадьбу идут кольшки смотреть. (с. Стояново, Одоев.) Перед свадьбой родители невесты смотрели колушки у жениха. (п. Арсеньево, Арсен.); колья считать (данное выражение синонимично приведенному выше). Колья считали некоторые, а зимой я выходила, не считали. (с. Стояново, Одоев.); лавочки смотреть (также употребляется как синонимичное выражение). У нас говорят не колыики смотреть, а лавочки смотреть, а так всё смотрят: и дом, и двор. (с. Симоново, Заок.). Еще были зафиксированы три выражения с подобным значением: полати смотреть, поместья смотреть, дом смотреть: Полати ездили смотрели перед свадьбой. (с. Нарышкино, Т-Огар.). Когда уж все слажено, невестина родня ходила поместья смотреть: куда невеста жить придет, хоромо ли ей будет. (с. Шилово, Ефрем.). Смотреть дом, окна мерить свекр, свекровя и'дуть. (п. Бельковский, Вен.).

Родня невесты посещала дом жениха не только для осмотра его хозяйства, подворья, но и для непосредственного приготовления к свадьбе и будущему проживанию невесты в доме у мужа. Обычно в процессе приготовления к свадьбе невеста должна была сшить занавески на окна, некоторые информанты нам рассказывали и о том, что если невеста богатая, то она могла сшить занавески и для того, чтобы отгородить свою с мужем постель, чтобы украсить печку, закрыть полати и т.д. Для того чтобы сшить занавески и подобным образом обустроить жизнь, необходимо было сначала измерить высоту окон, стен, дверей и т.д., поэтому часто встречаются такие выражения, как обмерять окна ('часть предсвадебного обряда, в процессе которой невеста или ее родня обмеряет окна и двери в доме жениха, чтобы 
сшить занавеси'). Невестина родня окна обмерять ходила. (д. Пруды, Волов.). Окошки обмерять - это занавески какие: хоть собачья конура, а всем подарки и занавески. (д. Пруды, Волов.). Следует сказать, что сам процесс снятия мерок превращался в шумное предсвадебное действие, веселое и задорное.

Непосредственно же перед свадьбой дом жениха необходимо было украсить, повесить новые шторы, рушники. Выражения, которые репрезентируют подобные действия, обычно указывают на то, что украшению подвергался только какой-то один элемент жилого помещения, чаще всего отмечается, что это угол: наряжать угол ('часть свадебного обряда, в ходе которого родственники невесты приходят в дом жениха украшать комнату, вешать занавески, иконы'). После выкупа крёстная невесты наряжает угол в доме жениха, а ей другие подсобляют. (с. Иевлево, Богор.). Угол наряжали: шторки вешали, святой угол обделают сначала под свадьбу. (д. Ново-Архангельское, Одоев.). Угол наряжали уже в день свадьбы, дынки были у невесты, восковой венеи и дынки. (с. Кузовка, Богор.). Думается, что такое устойчивое использование лексемы угол в данном случае вполне закономерно: угол становится символом начала новой жизни, частной, отдельной. В русском языке часто можно услышать: $y$ него не было своего угла, они получили свой угол, уйти в свой угол. В таких выражениях лексема угол имеет значение 'приют, пристанище', поэтому не удивительно, что и в выражениях, относящихся к свадебному обряду, это слово имеет расширительное употребление и используется в значении 'дом, жилье'.

Перед свадьбой договариваются о финансовой стороне, дают жениху деньги на начало семейной жизни, стараются произвести благоприятное впечатление на окружающих, в том числе на новых родственников. Или накануне свадьбы, или с утра в день свадьбы в дом родственников отправляется приданое. Все это множество действий отражено в следующих выражениях: выходные деньги ('денежная сумма, вкладываемая родителями жениха в свадебный пир и в обустройство домашнего хозяйства будущей молодой семьи'), уговорные деньги ('деньги, обещанные при сговоре, на «ладах»'). Предсвадебная ситуация может быть отражена в следующих конструкциях: на вы'хвал ('на показ; в ходе предсвадебной части женщины выносили на показ различные вещи'). Под свадьбу носили женщины рубаху, полотенце, перчатки, носки, эт носют на выхвал, чтоб удивить. (д. Пруды, Волов.). На первый день постель везут на выхвал. (д. Пруды, Волов.); напод то'ржино ('перед самой свадьбой, накануне свадьбы'). А на-под торжино ходили родители невесты к жениху, приносили подарок. (с. Непрядва, Волов.); идти с повестью ('приходить перед свадьбой к невесте с кашей'). Перед свадьбой вечером к невесте приходят с повестью. (с. Иевлево, Богор.).

Значительное место в предсвадебной части обряда имеет общение сторон по поводу приданого невесты. Об этом говорят так: выговаривать норму ('в процессе предсвадебной части обряда родственники жениха и невесты договариваются о том, что именно войдет в приданое невесты'). К невести приходили женихова родня и норму выговаривали, там зерница, картошки сколько, овеч$\kappa y$, может, дадут. Это норма такая была, вот за невесту норму выговаривали. (с. Стояново, Одоев.); везти постель ('отправлять в дом жениха приданое невесты'). Часть родственников невесты оставалась в доме и готовила к отправке приданое - постель везти. (Гайсина); везти постелку (употребляется в 
таком же значении). Постелку собирали и везли, у кого что: подушки, одеяки, думочки для ребеночка. (д. Пруды, Волов.). Здесь можно обратить внимание на то, что чаще всего совокупность приданого именовалась постелью, хотя могла в себя включать не только постельные принадлежности. Само приданое в тульских говорах именуется по-разному: сундук, коробка, короб, коробья.

К предсвадебной части обряда относили также различного рода посиделки в доме у невесты. Об этом говорили: пропойный день ('застолье вечером накануне свадьбы'). О невесте, которая уже была готова к свадьбе, обычно говорили, что ее пропили, поэтому довольно регулярно встречаются такие выражения, как пропитая девка ('просватанная невеста'). Да уж что про неё теперь говорить: она пропитая теперь девка. (с. Кузьмёнки, Арсен.). Непосредственно накануне свадьбы организовывали невестины посиделки ('девичник, посиделки невесты у неё в доме перед свадьбой'). Невестины посиделки проходили невесело, ревела я. (г. Ясногорск.).

Одно из посещений будущих родственников перед свадьбой называлось $x о$ дить за мылом ('часть предсвадебного обряда, в ходе которого подруги и родственники со стороны невесты шли к жениху за мылом'). За мылом часов 6 10-11 утра ходили, а часов с 10 вечера крёстные стелили постель, разбивали горшок, мелкие деньги на пол бросали, а невеста должна была что-то подарить.(с. Иевлево, Богор.). Сначала за мылом идут к жениху. (с. Иевлево, Богор.). Кандылихи-то свадьба была, мы с ёлкой по деревне за мылом ходили. (д. Кобылинка, Богор.). Подчеркнем, что такое действие могло происходить и утром в день свадьбы, по словам информантов. Тут хочется вспомнить о том, что баня является обязательной частью северного типа свадьбы. На территории тульского региона не отмечалась традиция ходить в баню в день свадьбы, но связанные с банными процедурами детали присутствуют.

Центральным днем всего свадебного обряда, конечно, считался сам день свадьбы. Итак, он начинался с того, что нужно было пробивать зорю ('встречать утро в день свадьбы песнями и ритуальными действиями'). $B$ самый день свадьбы парни с девушками зорю пробивали. (с. Свиридово, Вен.). Затем о начинающемся свадебном торжестве необходимо было оповестить местных жителей, то есть нужно было по селу с ёлкой ходить ('часть свадебного обряда, в ходе которой организаторы свадьбы приглашали гостей на свадебное пиршество, зазывали на свадьбу'). Перед свадьбой ходили с ёлкой и звали. (с. Иевлево, Богор.). Отметим, что слово ёлка в данном случае является словом, которое обозначает свадебный символ, свадебное дерево. Это действительно могла быть небольшая ёлочка, мог быть любой куст или даже высокая трава, например, репейник. Обычно свадебно дерево наряжали различными ленточками, цветными бумажками.

Когда подруги одевали и причесывали невесту, то она могла кричать в голос ('часть свадебного обряда, плач невесты'). А потом утром встають подружки, а невесты тогда в голос кричали: «Зоренька собирается - подруженьки собираются, хочут-хочут нас разлучить, милинькии подружсеньки». (д. Красный Холм, Волов.). В тульских говорах такие выражения сейчас встречаются непоследовательно. Однако элемент оплакивания невестой своей судьбы также выражается глаголами выть, плакать, которые нами были отмечены неоднократно в связи с описанием свадебного обряда. 
После того как жених оказывался в доме невесты, ему необходимо было брать норму ('часть свадебного обряда - символический выкуп невесты; получение семьей жениха даров от семьи невесты'). Норму брали родичи жениха, когда свататься приходила женихова родня, на сватушках - украшенья разные, а иной случай и что для хозяйства. (д. Ново-Архангельское, Одоев.). Затем шел процесс выкупа невесты: выкупать место ('в ходе свадебного обряда за специальную плату покупать место рядом с невестой'). Место выкуnать - это рядом с невестой, а нельзя посыпать мелочью и давать мелочь - такая жизнь и будет. (с. Стояново, Одоев.); окупать ёлку ('часть свадебного обряда, связанного с выкупом невесты'). Окупают ёлку, а невеста сидит за столом, бабуикам давали водки, закуски. Если согласны, то вылезали из-за стола, а если нет, то скалками стучат. (п. Одоев.); выкупать невесту ('часть свадебного обряда, в ходе которой за невесту вносится символическая плата, а сама невеста переходит к жениху'). Выкупали невесту весело, с шумом. (д. Горбачево, Одоев.); колодеи показывать ('часть свадебного обряда, в ходе которой его участники накрывали колодец тканью и просили за него выкуп'). Так вот девчонки станут у колодия и давай колодец показывать, значит денег им давай, а то водицы не дадут и в дом не пропустят. (д. Ливенское, Лен.).

Родня и подруги невесты должны были косу продавать ('часть свадебного обряда, в ходе которой подруги невесты получали специальный выкуп за косу невесты'). Бабы поют, косу продавали. (с. Стояново, Одоев.). Тут начинался настоящий торг - косу продавали, чтобы выпустить молодую из дому: водку брали и подарки, девчата голосили, дверь лентами завязывали, на невесту сеть накидывали. (п. Арсеньево, Арсен.). Ето называется косу продавать. (д. Кураково, Бел.). Косу продавали как на свадьбе-то было. (п. Арсеньево, Арсен.). Еще косу продавали. Када за столом сидять, подруга торг зативаить - за косу-то жених плотить. (с. Николо-Жупань, Одоев.).

Невеста в процессе выкупа сидела за ёлкой, о которой мы уже говорили выше, или - за садом ('деталь свадебного обряда, когда невеста сидит за свадебным деревом'). За садом кто сидит, за елкой-то? (д. Пруды, Волов.). В данном случае лексема сад - это переносное название одного свадебного дерева.

После выкупа невесты свадебный поезд двигался к церкви или в советское время - в администрацию сельских поселений, в сельсоветы, где должны были обвенчать или официально зарегистрировать брак. Перед этим жениха могли проверить на хозяйственность, то есть он должен был вожжу завожжать ('обычай на свадьбе, в ходе которого жениха заставляют запрячь лошадь, чтобы проверить его хозяйственность'). А ежли жаних важжу ни заважжаит, худой муш достанииа. (с. Шилово, Ефрем.). О самом процессе выезда из дома невесты говорится в следующем выражении: поднять невесту ('увозить невесту из родительского дома в дом жениха в день свадьбы'). Подарки дарили после того, как жених поднял невесту. (д. Горбачёво, Одоев.).

Когда в доме невесты оставались родственники или соседи, которые приходили посмотреть на выкуп невесты, то они могли овин тушить ('часть свадебного обряда - сбор соседей для того, чтобы доели и допили все, что осталось после свадебного застолья'). А тут собирались у нивести овин тушить. Это надо все поесть и выпить, что осталось. Соседей собирали. (д. Красный 
Холм, Волов.); овин горит ('обряд тушения фонаря, которым украшалось застолье в доме невесты'). Фонарь за один угол подвешивали к потолку. На следующий день его сжигали, когда невеста, жених и его родня приходили на застолье в дом невесты: дружок поджигал фонарь с восклицаниями, которые подхватывали другие присутствующие: «Овин горит!», - и сбрасывали его на пол. (Гайсина). В то время, пока молодых венчали, оставшиеся в доме невесты родственники, включая мать и отиа (к вениу с невестой ехали её крёстные родители) устраивали небольшое застолье (садились овин тушить), затем выезжали с приданым невесты к жениху - постель везли. (Гайсина).

В процессе движения свадебный поезд неоднократно останавливался местными жителями, которые организовывали различные препятствия на пути поезда. Об этом могли сказать так: верёвки тянуть ('в ходе свадебного обряда останавливать поезд с молодыми по дороге к церкви'). А ещё тогда верёвки тянули, молодых останавливали. (с. Свиридово, Вен.). После венчания нужно было подвязать вожжу ('часть свадебного обряда, во время которой невеста подаёт вознице вышитое полотенце, чтобы продолжить путь домой после венчания'). Выкупа от невесты мог потребовать и возница: он останавливал лошадь, утверждая, что вожжа оборвалась и её надо подвязать. Невеста подавала ему вышитое полотенце (подвязать вожжу), возница брал его, затыкал за пояс, и все ехали дальще. (Гайсина).

После венчания невесту переодевали. Из этой части обряда нами были записаны такие выражения, как рога делать ('причёска, при которой косы невесты (из крепостных крестьян) укладывались по разные стороны головы'). Koсы укладывались сзади (у вольных крестьян), либо по разные стороны головы рога делали (у крепостных крестьян). (Гайсина). И сюда же можно отнести еще одно выражение: надевать бабью сухоту ('в свадебном обряде - надевать на невесту поневу как символ супружеской жизни'). Матушки, подруженьки, // Не надевайте на мене бабью сухоту. (Песня). (с. Кресты, Кур.). На что ты, братеи, и девичью красоту снимаешь, бабью сухоту надеваешь? (Причитание). (с. Малёвка, Богор.). Понятно, что в первом выражении слово рога именует прическу, а во втором случае речь идет о символической и традиционной детали для южнорусского женского типа костюма - понёве.

В новый дом вместе с невестой могли приводить овцу, собинку, которую пускали во двор к другим животным, но чаще приносили с собой курииу-придан$\kappa y$, которую отпускали и смотрели, как она себя будет вести, не заклюют ли ее местные куры. По этому поведению курицы делали выводы о том, как будет жить невеста в доме жениха. Существует выражение в связи с этим: пускать курииу в курятник ('обычай во время свадебного обряда, при котором родственники невесты пускали курицу в курятник в доме жениха и наблюдали за происходившим, что должно было предопределить отношения в новой семье'). И когда приезжали к жениху, пускали курииу у курятник и смотрели. (д. НовоАрхангельское, Одоев.).

Сам свадебный обед назывался каравайный обед ('в свадебном обряде - обед у жениха для родственников невесты'); красный обед (в том же значении). $K$ жениху на красный обед едут. (с. Свиридово, Вен.). 
Обычно за обедом было довольно весело, но существовал некий условный порядок. Например, считалось, что старшее поколение должно научить молодых некоторым премудростям семейной жизни. Этот момент нашел отражение в таком выражении, как дорожку показать ('в ходе свадебного обряда какая-нибудь семейная пара или мать с отцом на свадьбе показывали молодым, как целоваться'). Дорожку нам показали, а мы не встали целоваться. (с. Иевлево, Богор.).

Подруги же невесты на свое счастье укладывали лапти под то место, где сидели молодые: лапти подтыкать ('часть свадебного обряда, в ходе которой подруги невесты клали лапти под шубу, на которой сидят молодые, чтобы выйти поскорее замуж').

Обычно в свадебный день было несколько застолий (хотя существует мнение, что второе застолье было уже на следующий день). Второе застолье могли называть также красный обед ('второй стол на свадебном пире, во время которого происходит одаривание молодых'). За красным столом и дарили подарки всем. (с. Прудищи, Вен.). Процесс преподношения подарков - важный момент в процессе застолья. Об этом часто говорят: дары дарить ('часть свадебного обряда, во время которого невеста дарит подарки семье жениха'). Застолье в доме жениха связано с ритуалом, имеютим название дары дарить. (Гайсина).

Естественно, что количество приглашенных на свадьбу гостей точно регламентировалось, остальные жители села просто приходили глядеть невесту ('перед свадьбой или во время свадьбы ходить со специальной целью - рассматривать невесту'). Вен. На девичник ходят пожилые женщины. И мы ходили глядеть невесту. (с. Свиридово, Вен.).

Ближе к моменту окончания застолья крестная мать, родственники или подруги невесты шли постель греть (обогревать) ('часть свадебного обряда, в ходе которой родные невесты ложились на постель перед молодой четой'). Постели грели, молодых укладали, свахи водили обогревать постель. (с. Стояново, Одоев.); обминать постель (употребляется в таком же значении). Под свадьбу собираются подруги и спят на этой постели, обминают ее, но у невесты дома. (с. Кузовка, Богор.). Перед свадьбой две подружски невесты ложились на постель и обминали её. (с. Кузовка, Богор.). Крестная мать обминает постель или подружки, крестная мать и с утра проверяет. (д. Пруды, Волов.). Подружки обминают постель. (д. Пруды, Волов.). Мы и ночи еще не ложились спать, постель только обминать пошли, постель убирали подружки. (п. Бельковский, Вен.).

Утро второго дня свадьбы именовалось наране свадьбы ('утро второго дня свадьбы'). Вероятно, в ранних версиях свадебного обряда второй стол приходился на утро следующего дня, наране свадьбы; в этом случае между застольями молодых отправляли спать. (Гайсина). О важности этого дня также говорят много, в частности символ этого дня - блин - запечатлен в названии самого сбора родственников на мероприятия этого дня: собираться на блины ('на второй день свадьбы приходить к невесте в гости'). Величальные пели песни, их трое, голоса-то должны быть хорошие, горшки били, собирались на блины у невесты. (г. Белев.).

Однако прежде чем невесте будут предъявляться какие-либо испытания ее следовало найти. Молодую жену, молодку, еще символично называли яркой 
('молодая овечка'). Поэтому сначала необходимо было ярку искать ('обычай, когда на второй день свадьбы родственники невесты (ряженые) шли в дом жениха искать невесту'). Ярку искать ходили на второй день свадьбы: невесту прятали, ага, было. Потом ее усе искали. (с. Николо-Жупань, Одоев.). Ярку искал молодой, как же без этого! (п. Арсеньево, Арсен.). Ярку обязательно искали. Приходили ряженые. (д. Горбачево, Одоев.). После свадьби, на второй день ярочку ищуть, приносють блинов напикуть, пасуду бьють. (д. Кураково, Бел.). Гости приезжают ярку искать. (с. Непрядва, Волов.). После свадьбы ищут ярку. (д. Хрусловка, Вен.). Там они собирают всю родню на завтрак. Здесь-то и выясняется. Что невеста пропала. Начинаются поиски ярки. («Как под яблонькой такой...»). Ярку обычно искало довольно определенное количество людей: милиционер, пастух, медсестра, цыганка, - которые также в некоторых районах Тульской области еще именовались чудаками, существует выражение: рядиться чудаками.

После того как невеста была найдена, ее подвергали ряду испытаний. В частности, могли бить горшки ('свадебный обычай: на второй день молодых будили биением горшков, после чего невеста заметала осколки'). С утра приходили, били горики. Горики пустые были. (с. Иевлево, Богор.). Невеста же должна была, например, вымести все черепки и при этом собрать все мелкие деньги, которые рассыпались вместе с осколками горшка. Ряд испытаний устанавливался для молодой семейной пары. Среди них часто встречается испытание, которое называется по воду ходить ('часть свадебного обряда, направленная на проверку сплоченности и взаимопонимания молодых супругов: на второй день свадьбы молодожены должны принести воды из колодца, все другие участники свадебного обряда создают при этом различные препятствия'). По воду с утра надо было ходить, a воду-то и не донесёшь, то ведро дадут худое, то воды нету. (д. Ливенское, Лен.). Стежка была у колодиа, туда по воду ходили, там стежку искали. (г. Белев.).

На второй день свадьбы также устраивалось застолье, которое именовалось княжсой пир ('застолье, угощение на второй день свадьбы'). В ходе этого застолья встречается действие, которое называли молить каравай ('действие на второй день свадьбы: дружка разрезает над головой молодоженов каравай, а затем трижды соединяет и разъединяет образовавшиеся половины; символ супружеского акта продолжения рода').

Таким образом, вариации в проведении свадебного обряда могут быть весьма многочисленными, но можно подчеркнуть, что устойчивые выражения, зафиксированные нами на территории распространения тульских говоров и представленные здесь далеко не в полном объеме, дают возможность проследить структуру и определенные этапы свадебного обряда. Они являются своего рода опорными пунктами в понимании последовательности действий южнорусской свадьбы. Если принять во внимание тот факт, что абсолютное большинство приведенных выше выражений имеет символическое значение, а слова, входящие в эти выражения, употребляются в переносном значении, то можно сделать вывод о том, что весь свадебный комплекс символичен, и это известное положение мы еще раз подтвердили с помощью обращения к семантике устойчивых выражений.

В свадебной терминологии можно выделять названия свадебных чинов, предметов и действий. В нашем случае на первый план выходят свадебные действия, так как в приведенных выражениях ключевым словом является глагол (в абсо- 
лютном большинстве случаев). По морфологической структуре основная часть зафиксированных нами выражений - это глагольные выражения, которые представляют собой словосочетания с главным словом - глаголом. Лишь несколько выражений можно отнести к субстантивным, так как они имеют в качестве главного слова существительное и называют какое-либо лицо или какую-то часть свадебного обряда. Приведенные выше выражения могут быть по-разному классифицированы, однако мы все-таки склонны их относить к типу фразеологических единств, так как в целом их обобщенно-целостное значение определенным образом связано со значением входящих в них компонентов.

Таким образом, в процессе анализа устойчивых конструкций, которые тематически можно отнести к группе обрядовых выражений, мы выявили их определенное единство, как формально-грамматическое, так и смысловое. Под смысловым единством мы имеем в виду репрезентацию ими элементов южнорусского свадебного обряда и представление довольно целостной картины русской свадьбы.

\section{Использованная литература}

Гайсина, Ю. В. Свадебный обряд в селе Стояново. Тульская область. Одоевский край. Очерки прошлого и настоящего. Москва: Институт наследия, 2007.

Гура, А. В. Брак и свадьба в славянской народной культуре: семантика и символика. Москва: Индрик, 2011.

Гура, А. В. О роли дружки в севернорусском свадебном обряде. Ленинград: Наука, 1979.

Зорин, Н. В. Русский свадебный ритуал. Москва: Наука, 2004.

Костромичева, М. В. Словарь свадебной лексики Орловщины. Орел: Изд-во ОГПИ, 1998.

Толстая, С. М. Пространство слова. Лексическая семантика в общеславянской перспективе. Москва: Индрик, 2008.

Нели Александровна Красовска

\section{ТЕРМИНОЛОГИЈА СВАДБЕНОГ ОБРЕДА У ЈУЖНОРУСКИМ ГОВОРИМА: ПОЈЕДИНОСТИ}

\section{Резиме}

У раду се разматрају устаљени изрази који су забележени током теренских истраживања на подручју јужноруских говора, конкретно у тулским говорима. Изрази припадају свадбеном обредном циклусу и могу се посматрати као саставни део словенске свадбене терминологије. Они репрезентују различите етапе (предсвадбену, свадбену и послесвадбену) свадбеног обреда, који се у целини може сматрати јужноруским, али у њему подједнако бележимо елементе средњеруског и северноруског обреда. Изрази које наводимо у раду углавном илуструју симболичке обредне радње. Управо из тог разлога њихов већи део заступљен је путем глаголских конструкција. Бележење и анализа сличних израза и дан данас представља један од важнијих задатака за истраживаче.

Кључне речи: руски говори, тулска група, руска свадба, свадбена терминологија, устаљени изрази. 